\title{
Examination of Causal Relationship Among Consumer Goods Price Index, Bovine, and Water Buffalo Milk Price in Turkey With Vector Error Correction Model
}

\author{
Şenol Çelik \\ Bingol University, Bingol, Turkey
}

\begin{abstract}
In this study, causalities among consumer goods price index (CPI), cattle milk price, and buffalo milk price are researched for Turkey using data covering the period from January 2005 to December 2014. The cointegration analysis and vector error correction model (VECM) are used the casualty relationship among CPI, cattle milk piece, and buffalo milk piece in estimating. According to unit root test, results indicate that each of series is not stationary, when the variables are defined in levels; but that each of series is stationary, when the variables are defined in first differences. Johansen's cointegration test results show that there exists a long-run equilibrium relationship among CPI, cattle milk piece, and buffalo milk piece. It is concluded that there are three cointegration vectors in the data. Since the series are found to be cointegrated, it used VECM model to test the existence of causality. According to the VECM, there has been no long-term relationship among the variables. In the results of cointegration analysis, its relation between cattle milk piece and CPI is found to be negative. However, a positive relationship has been found between cattle milk price and buffalo milk piece.
\end{abstract}

Keywords: unit roots, stationary, lag number, long-run changes, short-run changes, milk price

\section{Introduction}

Cow milk constitutes $83 \%$ of the world's total milk production. The total production in 2012 has increased by $2.1 \%$ compared to the previous year, while production increase in 2011 is being realized as $2.7 \%$ compared to the previous year. According to IFCN (International Farm Comparison Network) data, 2012 total bovine and water buffalo milk production have increased by $2.6 \%$ compared to the previous year in 2012 and have been calculated as a total of 739 million tons (IFCN, 2012). In Turkey, cow milk constitutes $91 \%$ of the total milk production (Turkish Statistical Institute [TSI], 2013).

According to research conducted by IFCN, raw milk price has varied from $\$ 8 / 100 \mathrm{~kg}$ to $\$ 44.5 / 100 \mathrm{~kg}$ in the world among the years from 1981 to 2012. While raw milk price has been reaching the highest level in history in 2007, they have decreased to $\$ 26.2 / 100 \mathrm{~kg}$ with a sharp decline in 2009. In 2011, raw milk price has increased to $\$ 44.5 / 100 \mathrm{~kg}$. For the first six months of 2013 , the average world raw milk price has been calculated as $\$ 49 / 100 \mathrm{~kg}$ (IFCN, 2012). In Turkey, the average milk price has been calculated as about

Şenol Çelik, assistant professor, Department of Biometry and Genetics Bingol, Zootechnics Department, Faculty of Agriculture, Bingol University, Bingol, Turkey.

Correspondence concerning this article should be addressed to Şenol Çelik, Faculty of Agriculture, Zootechnics Branch at Department of Animal, Bingol University, Bingol, 12000 Turkey. 


\section{\$45/100 kg (TSI, 2013).}

Bovine milk is the most valuable nutriment in economic profit $(\$ 4,986,060,000)$ and the second in production amount (15,977,837 tons) after wheat in Turkey (Food and Agriculture Organization [FAO], 2012). These data show that milk is an extremely important nutrient for Turkey.

The total world water buffalo milk production is $80,108,460$ tons. India ranks first with 70 million tons, China is the second with 3.05 million tons, and Egypt is the third with 2,614,500 tons of production. According to FAO data (2013), Turkey ranks 10th in water buffalo milk production among the world's countries. In Turkey, water buffalo milk production amount has reached the highest amount of 382,674 tons in 1951. Water buffalo milk production has amounted to 257,900 tons in $1960,279,000$ tons in 1970, 273,905 tons in 1980, 174,225 tons in $1990,67,330$ tons in 2000, 35,487 tons in 2010, 51,947 tons in 2013, and 54,687 tons in 2014 (TSI, 2013; 2015a).

In this study, unlike other studies, using vector error correction model (VECM) methods, the relationship among some animal product prices with consumer price index (CPI) is examined in terms of Turkey's economy.

The purpose of this study is to examine the long-term relations among bovine milk prices, water buffalo milk prices (BM), and CPI using Johansen co-integration method VECM in Turkey.

\section{Literature Review}

Most researchers discovered that, energy (oil) price fluctuation had a positive long-term equilibrium relationship on a nation's merchandise price level (Darby, 1982; Cunado \& De Gracia, 2003; Cologni \& Manera, 2008). Some researchers further made some quantitative measures to a nation or many nations' data and summarized the proportion of the variation of merchandise price caused by energy (oil) price (Mo \& Yin, 2007; Chen, 2009). The effect was investigated by the influence of coal price fluctuation on CPI (Ding, Zhou, \& Ning, 2011) and crude oil price pass-through to the macroeconomic activities (Alom, 2015).

\section{Data Definitions and Sources}

In this study, the CPI data are taken from TSI's web site: http://tuikapp.tuik.gov.tr/medas/? $\mathrm{kn}=84 \&$ locale $=\operatorname{tr}$ (TSI, 2015b). Data on bovine milk and BM variables are taken from Internet address: http:/tuikapp.tuik.gov.tr/tarimsalfiyatapp/tarimsalfiyat.zul under Agricultural Price Statistics (TSI, 2015c). These data are monthly data covering the period between January 2005 and December 2014.

\section{Research Methods}

Together with CPI causality analysis, co-integration analysis and VECM have been applied in order to analyze the relationship between bovine milk and BM in this study. Before the causality relationship is examined, the stability test of the series has been conducted. For determination of the stability of the series, augmented Dickey Fuller (Augmented Dickey Fuller-ADF) unit root test is performed (Dickey \& Fuller, 1981). The average, variance, and covariance values of a stable time series do not change over time (Darnell, 1994).

Dickey-Fuller test cannot be used if error terms contain autocorrelation. Autocorrelation in the error term can be removed using lag values the time series. A new test has been developed which includes lag value of Dickey-Fuller dependent variable into the model as independent variable. This test is Augmented Dickey-Fuller test. Here while the appropriate lag order of the lagged variable is being determined, Akaike and Schwarz 
criteria is being used (Enders, 1995). This test can be written in three different ways as in the equations (1), (2), and (3) (Asteriou \& Hall, 2007).

$$
\begin{gathered}
\Delta X_{t}=\gamma X_{t-1}+\sum_{i=1}^{k} \beta_{i} \Delta X_{t-i}+e_{t} \\
\Delta X_{t}=\alpha_{0}+\gamma X_{t-1}+\sum_{i=1}^{k} \beta_{i} \Delta X_{t-i}+e_{t} \\
\Delta X_{t}=\alpha_{0}+\alpha_{1} t+\gamma X_{t-1}+\sum_{i=1}^{k} \beta_{i} \Delta X_{t-i}+e_{t}
\end{gathered}
$$

ADF test statistically tests whether the $\gamma$ coefficient in the above mentioned equation equal to zero. The results obtained by the ADF test can be compared with MacKinnon critical values (1996) at 1\%, 5\%, and 10\% significance level. $\Delta X_{t}$ shows the primary difference of the time series which is analyzed to find out whether it is stable or not, $t$ is the general trend variable, and $X_{t-1}$ is the lagged difference terms in the analyses.

Pesaran, Shin, and Smith's approach (2001) provided the opportunity to include both variables $I(0)$ (level) and $I$ (1) (first-degree integrated) within the model and to test the existence of a long-run relationship between them. However, the requirement of this approach that the variables have to be at the level or to be integrated at the first degree and the requirements for the equal integration level of the variables for Johansen method to be used necessitate the determination of the integration degrees of the variables. For this purpose, unit root tests of the series in the model have been made.

Cointegration test is performed to determine whether the variables stable at the same degree are co-integrated or not (Kadılar, 2000). Since the calculation of the error terms in the co-integration analysis is connected to the co-integration parameter, Engle-Granger (EG) and augmented-EG (AEG) critical values are used for error terms (Engle \& Granger, 1987). Taking the difference of the series away, eliminating the impacts of the shocks the series has been exposed in the past, but it also causes the long-term relationship among the variables to disappear. The existence of a long-term relationship between the variables can be found by co-integration analysis (Tar1, 2014). Overall if variables are $I(d)$ and if $d$ has the same value, the variables are co-integrated and the regressions among them give reliable results (Gujarati \& Porter, 2012). According to Johansen co-integration test, it is conducted taking equation (4) into consideration (Turner, 2009).

$$
\Delta X_{t}=\alpha\left(\beta^{\prime} X_{t-1}-\beta_{0}-\beta_{1 t}\right)-\gamma_{0}-\gamma_{1 t}+\sum_{j=1}^{k} \Gamma_{j} \Delta X_{t-j}+\varepsilon_{t}
$$

Here, $X_{t}$ is $p \times 1$ vector of the variables observed in $t$ period; $\alpha$ is $p \times r$ coefficient matrix; $\beta$ is $p \times r$ coefficient matrix that defines the cointegrated vectors $r ; \beta_{0}$ is discrete $r \times 1$ vector for co-integrated vectors; $\beta_{1}$ is $r \times 1$ coefficient vector allowing the linear deterministic trend in co-integrated vectors; $\gamma_{0}$ is $p \times 1$ discrete vector in the equation; $\gamma_{1}$ is $p \times 1$ linear trend coefficient vector; and $\Gamma_{j}, j=1, \ldots, k$ represents the $p \times p$ matrix' up to $k$ that have lag length. If the series are co-integrated, the results obtained from Granger procedure applied to them will be invalid (Bahmani-Oskooee \& Alse, 1993). In this case, the error correction model is applied to causality test.

If a set of variables is found to have one or more cointegrating vectors, then a suitable estimation technique is a VECM which adjusts to both short-run changes in variables and deviations from equilibrium. Lag length criteria also suggest the chosen of one lag for estimating VECM. General form of VECM model used is: 


$$
\Delta Y_{t}=\alpha_{0}+\alpha_{1} E C T_{t-1}+\alpha_{2} \Delta Y_{t-1}+\alpha_{3} \Delta X_{t-1}+e_{t}
$$

A crucial parameter in the estimation of the VECM dynamic model is the coefficient of the error correction term $E C T_{t-1}$, which measures the speed of adjustment of economic growth to its equilibrium level. In order to establish the joint effect of variables, under VECM, all those variables are taken as endogenous $(\Delta Y)$ and exogenous $(\Delta X)$, in order to establish the long- and short-run association between them. It is applied a VECM model with one cointegrating equation and under eviews environment estimate with OLS, a system of equations, ordered by each variable. Short-run effects are captured through individual coefficients of the differentiated terms. That captures the impact while the coefficient of the VECM variable contains information about whether the past values of variables affect the current values of the variables under study. The size and statistical significance of the coefficient of the error correction term measure the tendency of each variable to return to the equilibrium. A significant coefficient implies that past equilibrium errors play a role in determining the current outcomes captures the long-run impact (D. M. Andrei \& L. C. Andrei, 2015).

If there is a co-integration relationship among the series, a VECM is estimated as in equation (6).

$$
\Delta X_{t}=\delta+\sum_{i=1}^{k-1} \gamma_{i} \Delta X_{t-i}+\Omega E C T_{t-1}+\varepsilon_{t}
$$

Here expression $E C T_{t-1}$ shows the error correction term. The equations forming VECM with multi variable used in the equation (6) can be written as follows:

$$
\begin{aligned}
& \Delta I S_{t}=\beta+\sum_{i=1}^{k} \beta_{1 i} \Delta I S_{t-i}+\sum_{i=1}^{1} \beta_{2 i} \Delta M S_{t-i}+\sum_{i=1}^{1} \beta_{3 i} \Delta C P I_{t-i}+\theta E C T_{t-1}+\varepsilon_{1 t} \\
& \Delta M S_{t}=\delta+\sum_{i=1}^{k} \delta_{1 i} \Delta M S_{t-i}+\sum_{i=1}^{1} \delta_{2 i} \Delta I S_{t-i}+\sum_{i=1}^{1} \delta_{3 i} \Delta C P I_{t-i}+\gamma E C T_{t-1}+\varepsilon_{2 t}
\end{aligned}
$$

Defined in equations (7) and (8), $E C T_{t-1}$ decodes the error correction term which means the error terms derived from the co-integration regression. $\varepsilon_{1 t}$ and $\varepsilon_{2 t}$ show the error terms of the relevant equations. Estimated parameters which belong to the error correction terms in the equations ( $\theta$ and $\gamma$ in these equations) being different than zero in terms statistics show that there is a long-term equilibrium among the variables. These parameters are referred to as adjustment speed parameters, since they show in which rate the deviations in the short-run return to the equilibrium state again in the long run.

The parameter of the ECT's in the equations being statistically different than zero is sufficient to establish the causal relationship, the parameter of other variables as group is not required to be different than zero. In order to establish the causality relationship in equations (7) and (8), $\beta_{1 i}, \beta_{2 i}, \delta_{1 i}$, and $\delta_{2 i}$ do not need to be different than zero as group (Granger, 1988). In short, the lag values of the independent variables in the VECM represent short-term causal effects, while the error correction term represents long-term causal effects (Love \& Chandra, 2005).

\section{Research Results}

Cointegration analysis has been used to determine the relationship between bovine milk and BM with CPI and causality analysis using vector error correction to determine the short-term relationships. To perform this analysis, primarily the variables are determined to be static or not with the unit root test. If the variables are not 
static, but static on their first difference, the long-run equilibrium relationship is determined. If there is a co-integration relationship among the variables, short-term causality results are interpreted estimating VECM.

In order to determine whether the series does or does not contain unit roots, ADF unit root test has been conducted. The results of the ADF unit root test of the variables used in the study are presented in Table 1. When Table 1 is examined, it is understood that zero hypothesis related to unit root is accepted in CPI cow milk price $(\mathrm{CM})$ and $\mathrm{BM}$ variables and that the variables at the level values are not static. According to the results shown in Table 1, the variables are free from unit root in the first differences and they are static. Thus CPI, CM, and BM variables are determined to be static $I(1)$ in the first differences $(P<0.01)$.

Table 1

ADF Unit Root Tests of Variables

\begin{tabular}{|c|c|c|c|c|c|c|c|}
\hline \multirow[t]{2}{*}{ Variables } & \multicolumn{3}{|c|}{ Level } & \multicolumn{3}{|c|}{ 1st difference } & \multirow[t]{2}{*}{ Result } \\
\hline & $t$ & $\begin{array}{l}\text { Test critical } \\
\text { values }\end{array}$ & $P$ & $t$ & $\begin{array}{l}\text { Test critical } \\
\text { values }\end{array}$ & $P$ & \\
\hline CPI & -2.741086 & $\begin{array}{l}-3.487046 \\
(1 \%) \\
-2.886290 \\
(5 \%) \\
-2.580046 \\
(10 \%)\end{array}$ & 0.0702 & $-8.845687 * *$ & $\begin{array}{l}-3.488063 \\
(1 \%) \\
-2.886732 \\
(5 \%) \\
-2.580281 \\
(10 \%)\end{array}$ & 0.0000 & $\mathrm{I}(1)$ \\
\hline IS & -0.369978 & $\begin{array}{l}-3.486551 \\
(1 \%) \\
-2.886074 \\
(5 \%) \\
-2.579931 \\
(10 \%)\end{array}$ & 0.9095 & $-8.297333^{* *}$ & $\begin{array}{l}-3.486551 \\
(1 \%) \\
-2.886074 \\
(5 \%) \\
-2.579931 \\
(10 \%)\end{array}$ & 0.0000 & $I(1)$ \\
\hline MS & 0.553437 & $\begin{array}{l}-3.486064 \\
(1 \%) \\
-2.885863 \\
(5 \%) \\
-2.579818 \\
(10 \%)\end{array}$ & 0.9879 & $-10.26036^{* *}$ & $\begin{array}{l}-3.486551 \\
(1 \%) \\
-2.886074 \\
(5 \%) \\
-2.579931 \\
(10 \%)\end{array}$ & 0.0000 & $I(1)$ \\
\hline
\end{tabular}

Notes. $* *$ is $P<0.01$; the lag number is 1 , where CPI is consumer goods price index, CM is cow's milk price, and BM is water buffalo milk price.

In order to specify the optimal $\operatorname{lag}(k), \log L$ statistics - $\log L, \mathrm{LR}$ - sequential modified LR test statistic (each test at 5\% level), FPE-final prediction error, AIC-Akaike information criterion, SC-Schwarz information criterion, LM-Lagrange multiplier, and HQ-Hannan-Quinn information criterion values are displayed in Table 2. When Table 2 is examined, it is seen that the model with the lag number "1" according to LR, FPE, AIC, SC, and HQ values should be selected.

Since CPI, CM, and BM variables are static in the first differences, the existence of a long-term relationship among these variables is examined via co-integration test, according to Johansen method (1988) and Johansen-Juselius method (Johansen \& Jeselius, 1990). The obtained results are presented in Tables 3 and 4. In Tables 3 and 4, it is shown that at least three co-integrated vectors are found in co-integration tests conducted to identify the numbers of co-integrated vectors. When Table 3 is examined, it is seen that while $\lambda_{\mathrm{i}}$ is showing self- values, the hypothesis $\mathrm{H}_{0}\left(\mathrm{H}_{0}: r=0, \mathrm{H}_{0}: r \leq 1\right.$ v.e. $\left.\mathrm{H}_{0}: r \leq 2\right)$ showing that no co-integrated vector is available is tested against the hypothesis $\mathrm{H}_{1}$ arguing that at least three co-integrated vectors are available. As a result, it is found out that three cointegrated vectors are available $(P<0.01)$. 
Table 2

Statistics for the Selection of the Number of Lag

\begin{tabular}{lllllll}
\hline Lag & Log $L$ & LR & FPE & AIC & SC & HQ \\
\hline 0 & -716.9981 & NA & 86.42770 & 12.97294 & 13.04617 & 13.00265 \\
1 & -683.3529 & $64.86547^{*}$ & $55.44232^{*}$ & $12.52888^{*}$ & $12.82180^{*}$ & $12.64771^{*}$ \\
2 & -674.5513 & 16.49299 & 55.66369 & 12.53246 & 13.04507 & 12.74041 \\
3 & -667.4552 & 12.91362 & 57.66205 & 12.56676 & 13.29907 & 12.86384 \\
4 & -664.3477 & 5.487238 & 64.23442 & 12.67293 & 13.62493 & 13.05913 \\
5 & -660.0143 & 7.417485 & 70.06678 & 12.75701 & 13.92870 & 13.23233 \\
6 & -652.1885 & 12.97255 & 71.86216 & 12.77817 & 14.16955 & 13.34261 \\
7 & -644.9866 & 11.54885 & 74.65579 & 12.81057 & 14.42164 & 13.46413 \\
8 & -638.0650 & 10.72537 & 78.09757 & 12.84802 & 14.67878 & 13.59071 \\
\hline
\end{tabular}

Note. $*$ indicates lag order selected by the criterion.

Table 3

Cointegration Trace Test Results

\begin{tabular}{lllll}
\hline Hypothesized No. of CE(s) & Eigenvalue & Trace statistic & 0.05 critical value & Prob.** \\
\hline None $(r=0)^{*}$ & 0.630429 & 193.1254 & 29.79707 & 0.0001 \\
At most $1(r \leq 1)^{*}$ & 0.332778 & 76.66231 & 15.49471 & 0.0000 \\
At most $2(r \leq 2)^{*}$ & 0.221667 & 29.32035 & 3.841466 & 0.0000 \\
\hline
\end{tabular}

Notes. Trace test indicates three cointegrating eqn(s) at the 0.05 level: * denotes rejection of the hypothesis at the 0.05 level and ** is MacKinnon-Haug-Michelis $p$-values (MacKinnon, Haug, \& Michelis, 1999).

Table 4

Maximum Eigenvalue Test Results

\begin{tabular}{llccl}
\hline Hypothesized No. of CE(s) & Eigenvalue & Max-Eigen statistic & 0.05 critical value & Prob. $^{* *}$ \\
\hline None* & 0.630429 & 116.4631 & 21.13162 & 0.0001 \\
At most $1 *$ & 0.332778 & 47.34196 & 14.26460 & 0.0000 \\
At most 2* & 0.221667 & 29.32035 & 3.841466 & 0.0000
\end{tabular}

Notes. Trace test indicates three cointegrating eqn(s) at the 0.05 level: * denotes rejection of the hypothesis at the 0.05 level and ** is MacKinnon-Haug-Michelis $p$-values (MacKinnon, Haug, \& Michelis, 1999).

Trace statistics value calculated as $193.1254,29.79707$ is greater than the critical value of 29.79707 . Besides, $r \leq 1$ and $r \leq 2$ hypotheses are also rejected. Similarly, the rank test 116.4631 (largest self-values) value is greater than the critical value of 21.13162. Also, $r \leq 1$ and $r \leq 2$ hypotheses are rejected $(P<0.01)$. Therefore, co-integrating vectors are observed in the model. According to the co-integration test results, there is a long-term relationship among CPI, bovine milk prices, and BM. According to the results obtained for $k=1$ according to $\lambda_{\text {trace }}$ statistics, the rank number has been obtained as $3(P<0.01)$; according to $\lambda_{\max }$ statistics, the rank number has been obtained as $3(P<0.01)$.

According to the results given in Table 5, the price of bovine milk, water buffalo milk, and CPI values have affected themselves negatively after a period of delay (respectively $0.433,0.006$, and $-8.17 \mathrm{E}-08$ ). When the bovine milk price is the dependent, variables BM' and CPI's impact are statistically insignificant. Furthermore, 1-unit increase in the price of water buffalo milk and CPI causes a unit of 0.006 and 0.00000008 respectively decrease in bovine milk prices. Since the impact of this decrease is insignificant, a short-term 
causality from bovine milk price towards water buffalo price and CPI cannot be identified. The error correction term $\left(E C T_{t-1}\right)$ coefficient has been found as -0.00029 and as statistically insignificant. In this case, no long-term causality from bovine milk price towards BM and CPI is identified (equation (7)). When BM is dependent and bovine milk price and CPI are independent variables, bovine milk price and CPI values affect themselves after a delay period negatively (respectively $0.495,0.489$, and $-4.55 \mathrm{E}-07$ ). Since this impact is statistically insignificant, a short-term causality from water buffalo price towards bovine milk price and CPI cannot be identified. The error correction terms $\left(E C T_{t-1}\right)$ coefficient have been found as -0.00034 and as statistically insignificant. In this case, no long-term causality from BM towards bovine milk price and CPI is identified. Additionally, 1-unit increase in the price of bovine milk and in CPI causes a unit of respectively 0.489 and 0.00000046 decrease in BM (equation (8)). Also lagged error correction terms $\left(E C T_{t-1}\right)$ show that deviation between bovine milk and $\mathrm{BM}$ values and long-term values disappear up to respectively $0.029 \%$ and $0.034 \%$ each year. According to the statistical tests of the models, the model determination coefficients $\left(R^{2}\right)$ are determined to be 0.194 and 0.278 respectively. By $F$ test, both models as a whole are found significant $(P<$ 0.01). As the result of DW statistical values, the models do not show any autocorrelation.

Table 5

VECM Models Results

\begin{tabular}{|c|c|c|c|c|c|}
\hline \multicolumn{3}{|c|}{ Dependent variable: $I S$} & \multicolumn{3}{|c|}{ Dependent variable: $M S$} \\
\hline $\begin{array}{l}\text { Independent } \\
\text { variable }\end{array}$ & Coefficient & $t$ & $\begin{array}{l}\text { Independent } \\
\text { variable }\end{array}$ & Coefficient & $t$ \\
\hline Sabit & $2.66 \mathrm{E}-06$ & 0.0013 & Sabit & 0.0002 & 0.0307 \\
\hline$I S-1$ & -0.433216 & -5.0497 & $M S-1$ & -0.4945 & -5.7956 \\
\hline$M S-1$ & -0.006157 & -0.2431 & $I S-1$ & 0.4889 & 1.6918 \\
\hline CPI-1 & $-8.17 \mathrm{E}-08$ & -0.2225 & $C P I-1$ & $-4.55 \mathrm{E}-07$ & -0.3680 \\
\hline$E C T_{t-1}$ & -0.00029 & -0.1075 & $E C T_{t-1}$ & -0.00034 & -0.0132 \\
\hline$R^{2}$ & 0.194 & & $R^{2}$ & 0.278 & \\
\hline$F$-ist. & $6.757^{* *}$ & & $F$-ist. & $10.785^{* *}$ & \\
\hline DW & 2.134 & & DW & 2.319 & \\
\hline
\end{tabular}

\section{Discussion}

Coal price fluctuation has a certain conducing effect on China's CPI. From the view of long-term effect size, coal price fluctuation and CPI are positively correlated (Ding et al., 2011). The obtained results do not coincide with the results in this study.

It was shown that there was unilateral causal relationship from exports to economic growth in the short run and from economic growth to external debt, whereas there was no causal relationship between exports and external debt (Dritsaki, 2013).

D. M. Andrei and L. C. Andrei (2015) examined the causal relationship among certain economic indicators by using VECM model in the study. Results of the paper approach were started by no macroeconomic development without FDI. Then, there came the rule that all FDI's influences appear negative, on exports, imports, GDP, and even on labour force, for which though context stays different than the other indicators' ones. The results from this study disagree with the results in previous research in some way. 


\section{Conclusions}

The purpose of this paper was to make statistical analysis and examine the causal relationship among CPI, CM, and buffalo milk price in Turkey by using VECM model. This study contributes to making understood cointegrating and causal relationship among CM, buffalo milk price, and CPI in Turkey case. To develop this study, the Johansen approach to cointegration test was used. VECM was used in order to test for the presence of a long-run relationship among these variables.

Bovine milk prices, water buffalo prices, and CPI variables are found to be co-integrated in Turkey in the period from January 2005 to December 2014. A positive correlation is found between the amount of bovine milk and buffalo milk and a negative correlation between bovine milk amount and CPI, when a single co-integrated vector is taken.

According to VECM results, no long- and short-term causal relationship is found from bovine milk price to $\mathrm{BM}$ and the $\mathrm{CPI}$ and no long- and short-term causal relationship is found from $\mathrm{BM}$ to bovine milk price and the CPI.

\section{References}

Alom, F. (2015). An investigation into the crude oil price pass-through to the macroeconomic activities of Malaysia. Energy Procedia, 79, 542-548.

Andrei, D. M., \& Andrei, L. C. (2015). Vector error correction model in explaining the association of some macroeconomic variables in Romania. Procedia Economics and Finance, 22, 568-576.

Asteriou, D., \& Hall, S. (2007). Applied econometrics. A modern approach using eviews and microfit. New York: Palgrave Macmillan.

Bahmani-Oskooee, M., \& Alse, J. (1993). Export growth and economic growth: An application to cointegration and error corerection modelling. The Journal of Developing Areas, 27, 535-542.

Chen, S. S. (2009). Oil price pass through into inflation. Energy Economics, 31(1), 126-133.

Cologni, A., \& Manera, M. (2008). Oil prices, inflation and interest rates in a structural cointegrated VAR model for the G-7 countries. Energy Economics, 30(3), 856-888.

Cunado, J., \& De Gracia, F. P. (2001). Do oil price shocks matter? Evidence for some European countries. Energy Economics, 25(1), 137-154.

Darby, M. R. (1982). The price of oil and world inflation and recession. American Economic Review Paper and Proceedings, 72 , 738-751.

Darnell, A. C. (1994). A dictionary of econometrics. Bodmin-Cornwall, England: Hartnolls Limited.

Dickey, D. A., \& Fuller, W. A. (1981). Likelihood ratio statistics fot autoregressive time series with a unit root. Econometrica, 49(4), 1057-1072.

Ding, Z. H., Zhou, M. H., \& Ning, B. (2011). Research on the influencing effect of coal price fluctuation on CPI of China. Energy Procedia, 5, 1508-1513.

Dritsaki, C. (2013). Causal nexus between economic growth, export and government debt: The case of Greece. Procedia Economics and Finance, 5, 251-259.

Enders, W. (1995). Applied econometric time series. New York: Jonh Wiles \& Sons, Inc.

Engle, R. F., \& Granger, C. W. J. (1987). Co-integration and error correction: Representation, estimation, and testing. Econometrica, 55, 251-276.

Food and Agriculture Organization [FAO]. (2012). Food and Agriculture Organization of the United States. Retrieved from http://faostat.fao.org/site/339/default.aspx

Food and Agriculture Organization [FAO]. (2013). Statistical database of Food and Agriculture Organization of the United Nations. Retrieved from http://faostat3.fao.org/download/Q/QL/E

Granger, C. W. J. (1988). Some recent development in a concept of causality. Journal of Econometrics, 39(1-2), 198-211.

Gujarati, D. N., \& Porter, D. C. (2012). Temel ekonometri. İstanbul: Literatür Yayınları.

International Farm Comparison Network [IFCN]. (2012). International Farm Comparison Network dairy report. Retrieved from http://www.ifcndairy.org/en/start/index.php 
Johansen, S. (1988). Statistical analysis of cointegration vectors. Journal of Economic Dynamics and Control, 12, 231-254.

Johansen, S., \& Juselius, K. (1990). Maximum likelihood estimation and inference on cointegration with applications to the demand for money. Oxford Bulletin of Economics and Statistics, 52(2), 169-209.

Kadılar, C. (2000). Uygulamalı çok değişkenli zaman serileri analizi. Ankara: Bizim Büro Basımevi.

Love, J., \& Chandra, R. (2005). Testing export-led growth in South Asia. Journal of Economic Studies, 32(2), 132-145.

MacKinnon, J. G. (1996). Numerical distribution functions for unit root and cointegration tests. Journal of Applied Economics, 11, 601-618.

MacKinnon, J. G., Haug, A. A., \& Michelis, L. (1999). Numerical distribution functions of likelihood ratio tests for cointegration. Journal of Applied Econometrics, 14, 563-577.

Mo, Z., \& Yin, J. (2007). International oil price fluctuated in dozens of industrial department. China Oil and Chemistry, 2007(3), 24-29.

Pesaran, M. H., Shin, Y., \& Smith, R. J. (2001). Bounds testing approaches to the analysis of level relationships. Journal of Applied Econometrics, 16, 289-326.

Tarı, R. (2014). Ekonometri (Umuttepe Yayınları, Kocaeli Üniversitesi Umuttepe Yerleşkesi Sosyal Tesisler Binası Z-16).

Turkish Statistical Institute [TSI]. (2013). Hayvancllk istatistikleri. Retrieved from http://tuikapp.tuik.gov.tr/hayvancilikapp/hayvancilik.zul

Turkish Statistical Institute [TSI]. (2015a). Hayvansal Üretim İstatistikleri, 2014 (Türkiye İstatistik Kurumu Haber Bülteni, Ankara, Turkey).

Turkish Statistical Institute [TSI]. (2015b). Data file. Retrieved from http://tuikapp.tuik.gov.tr/medas/?kn=84\&locale=tr

Turkish Statistical Institute [TSI]. (2015c). Tartmsal fiyat istatistikleri. Retrieved from http://tuikapp.tuik.gov.tr/tarimsalfiyatapp/tarimsalfiyat.zul

Turner, P. (2009). Testing for cointegration using the Johansen approach: Are we using the correct critical values? Journal of Applied Econometrics, 24, 825-831. 